\title{
Online Media Usage in Guidance and Counseling Services during Covid-19 Pandemic
}

\author{
(Penggunaan Media Online dalam Layanan Bimbingan dan Konseling pada Masa Pandemi \\ Covid 19) \\ Maria Margaretha Sri Hastuti*, Prias Hayu Purbaning Tyas \\ Department of Guidance and Counseling, Faculty of Teacher Training and Education, Universitas Sanata Dharma, \\ Affandi St., Sleman, Special Region of Yogyakarta, 55281 Indonesia \\ *corresponding author, e-mail: rethahrd@gmail.com
}

Article received: January $30^{\text {th }} 2021$; revised: April $26^{\text {th }} 2021$; accepted: May $19^{\text {th }} 2021$

\begin{abstract}
The Covid-19 pandemic has brought restraints into people's activities. Consequently, during the pandemic, the school guidance and counseling services should be conducted online. Therefore, this study seeks to identify the types of online media frequently used by school counselors in classical guidance and individual or group counseling, as well as the rationale. This descriptive quantitative study involved 106 school counselors and used an Online Media Usage questionnaire to obtain the data. The results suggest that Google Form and Google Classroom have become the most used applications in classical guidance, while WhatsApp is the most popular application for individual or group counseling. These applications are selected due to the limited internet access, students' technological literacy, students' financial state, and privacy assurance, primarily for the counseling process. Therefore, the school counselors mainly provide asynchronous rather than synchronous services during the Covid-19 pandemic. Besides, these results can be the foundation for online guidance and counseling services development.
\end{abstract}

Keywords: online media; guidance and counseling services; online guidance and counseling

\begin{abstract}
Abstrak: Pandemi Covid-19 memaksa kita untuk menyesuaikan diri agar tetap dapat beraktivitas walau dalam keterbatasan. Dalam bimbingan dan konseling, layanan yang diberikan oleh konselor sekolah saat ini harus dilakukan secara daring karena alasan kesehatan. Studi ini bertujuan untuk mengetahui macam media online yang sering digunakan oleh konselor sekolah untuk pelayanan bimbingan klasikal dan konseling individual atau kelompok serta kondisi-kondisi yang melandasi pemilihannya. Penelitian kuantitatif deskriptif dengan desain survei ini melibatkan 106 konselor sekolah sebagai responden. Pengumpulan data menggunakan Angket Survei Penggunaan Media Online. Hasil menunjukkan bahwa aplikasi Google Classroom dan Google Form sering digunakan sebagai media untuk bimbingan klasikal, dan aplikasi WhatsApp untuk konseling individual/kelompok. Sementara kondisi-kondisi yang melandasi pemilihan media online adalah keterbatasan jaringan internet, kemampuan pemanfaatan teknologi informasi peserta didik, kemampuan finansial peserta didik, dan terjaminnya kerahasiaan khususnya untuk konseling. Dari hasil studi ini, dapat diketahui bahwa pada masa pandemi Covid 19 ini pelayanan konselor sekolah cenderung lebih banyak asynchronous daripada synchronous. Hasil penelitian ini dapat menjadi dasar penelitian pengembangan pelayanan bimbingan dan konseling berbasis daring.
\end{abstract}

Kata kunci: media online; pelayanan bimbingan dan konseling; bimbingan dan konseling online 


\section{INTRODUCTION}

Due to the Covid-19 pandemic, countries have implemented several new protocols, such as work from home, study from home, social distancing, and physical distancing (Boshra et al., 2020; Chu et al., 2020; Koh, Naing, \& Wong, 2020; Liebrenz, Bhugra, Buadze, \& Schleifer, 2020; Qureshi, Suri, Chu, Suri, \& Suri, 2021; Sammer, Sher, Huisman, \& Seghers, 2020; Savić, 2020). Similarly, in Indonesia, all learning activities are carried out from home since the government enforced the work from home and stayed at home regulation. Consequently, teachers have to teach from home, while the students also learn from home, using online media and schedules arranged by the schools. Thus, the guidance and counseling services are also carried out online.

The online guidance and counseling services practice requires the school counselors to be creative, innovative, and productive (Perdana \& Shofaria, 2020; Petrus \& Sudibyo, 2017). These attributes aid students to evade boredom caused by the learning pattern transition and facilitate the counselor to select the proper services (Nugroho, 2020). Therefore, during the pandemic, guidance and counseling service should be carried out intensively (Karaman, Eşici, Tomar, \& Aliyev, 2021; Meleo-Erwin, Kollia, Fera, Jahren, \& Basch, 2021).

In online guidance and counseling services, the communication can be carried out asynchronously or synchronously. The asynchronous communication provides a delay between the contacts, while the synchronous communication occurs at the same time (Barak, Klein, \& Proudfoot, 2009; Dowling \& Rickwood, 2013). Situmorang (2020) mentions a proper counseling service for the pandemic situation, which is usually referred to by a number of terms, such as online counseling or therapy, Internet counseling or therapy, cybertherapy, e-therapy (e-counseling), computer-mediated therapy, and webbased intervention (Dowling \& Rickwood, 2013; Lau, Jaladin, \& Abdullah, 2013). Asynchronous online therapy has been frequently implemented (Chester \& Glass, 2006), along with synchronous online counseling carried out through chat and video conference (Bambling, King, Reid, \& Wegner, 2008). In Indonesia, online counseling has been massively discussed (Ifdil \& Ardi, 2013; Kirana, 2019; Prabawa, Ramli, \& Fauzan, 2018; Prasetya, 2017) and many research on this topic has been reported (Bangun \& Saragih, 2015; Mansyur, Badrujaman, Imawati, \& Fadhillah, 2020; Prabawa et al., 2018; Prahesti \& Wiyono, 2017; Setyawan, 2019; Sukoco KW \& Budiman S, 2019; Sutijono \& Farid, 2018).

However, implementation of online counseling still carries several complexities since its differences with offline counseling that demands particular competence. Substantially, school counselors use applications, such as WhatsApp, Zoom, Webex, Google Meet, Hangout, Telegram, and Instagram as the media for the counseling process (Musdalifah, 2020; Sholihah \& Handayani, 2020; Supriyanto et al., 2020). In addition to the counseling services, school counselors also conduct classical guidance. The data obtained through the initial interview reveal that the classical guidance is carried out through WhatsApp Group. The classical guidance serves as an information delivery facility, with a number of materials in PowerPoint presentations. Scribe videos, and other videos, sent through WhatsApp Group. Besides, the school counselors also frequently adopt Google Classroom and Zoom, along with Google Form, to respond to reflective questions. The tendency to conduct online asynchronous classical guidance signifies the one-way communication among school counselors and students.

The complexity of online counseling and the less practical classical guidance have indicated that online media usage in guidance and counseling services should be investigated intensively. Thus, this study aims to illustrate the implementation of online guidance and counseling services during the Covid-19 pandemic, along with the constraints experienced by the school counselors. Specifically, this study aims to identify: (1) the online media frequently used by the school counselors for the classical guidance; (2) online media used in individual and group counseling; and (3) the rationales behind those online media selections.

\section{METHOD}

This descriptive quantitative study used the survey method. The data were analyzed by estimating the frequencies and percentages, which were then visualized in the pie and bar charts. This study involved 288 Department of Guidance and Counseling, Universitas Sanata Dharma graduates who worked as school counselors in junior, senior, and vocational schools. The participants were from different areas of 
Indonesia, namely North Sumatera, Lampung, Jakarta, Bogor, Depok, Tangerang, Bekasi, Java (West, Central, and East), Kalimantan (West and East), Bali, Sumba, Sulawesi, and Papua. This study adopted a simple random technique, with 50\% samples in each area, since it had time limitations and considered similar opportunities from every region of the participants. Thus, the total participants were 114 people (50\%). However, only 106 (around 37\%) of participants had been obtained in 2 months through the Online Media Usage Questionnaire, distributed through Google Form.

The survey method facilitated this study to attain more significant information from the respondents. Meanwhile, the adopted questionnaire consisted of 20 items (close-ended questions) for the try-out phase and 22 items (close-ended questions) for the research stage. The components covered in the questionnaire were: (1) identity, (2) technological and informatics competence, (3) online media selection reasoning, (4) the online media usage frequency for the classical guidance, (5) the frequency of online media used in the individual and group counseling, and (7) self-made and self-developed media for the guidance and counseling services. The questionnaire was validated by experts on online guidance and counseling media content. The content validity test was carried out to identify the conformity between the item formulation and the questionnaire's components (outline). Simultaneously, the questionnaire items' readability was completed by 26 school counselors.

The validity test results on the conformity between the questionnaire's outline and research purposes were explained narratively. The experts' suggestions in the form of qualitative data were not quantified, as presented in Table 1. Meanwhile, the results of the questionnaire's readability test from 26 counselors were in the form of recommendations. The readability test covers the delivery in the Google Form, conformity between the answer with the reality, clarity of item formulation, and the answer. The detailed results of the readability test are presented in Table 2.

Table 1. The Results of Content Validity Test

\begin{tabular}{|c|c|c|}
\hline No & Aspect & Assessment Results \\
\hline 1 & $\begin{array}{l}\text { Suitability between the } \\
\text { outline and purpose }\end{array}$ & The conformity between the outline and purposes have been excellent. \\
\hline \multirow[t]{2}{*}{2} & Identity & $\begin{array}{l}\text { 1. The economical status option (high, middle, and low) is less operational. } \\
\text { It should target the more detailed information, such as the monthly family } \\
\text { income, or provide more apparent options with clear definitions of the high, } \\
\text { middle, and low economy. }\end{array}$ \\
\hline & & $\begin{array}{l}\text { 2. One of the options on the individual counseling services said that it could } \\
\text { be scheduled. It might trap people to believe that individual counseling could } \\
\text { be scheduled, while it could not. }\end{array}$ \\
\hline 3 & $\begin{array}{l}\text { Technology } \\
\text { and informatics } \\
\text { competencies }\end{array}$ & $\begin{array}{l}\text { The provided items could not reveal the teachers' technology and informatics } \\
\text { competencies. It only identified their relevant efforts to improve their } \\
\text { competencies, such as by attending training. The instruments initially aimed } \\
\text { to see the school counselors' competencies that had been implemented. }\end{array}$ \\
\hline 4 & $\begin{array}{l}\text { The online media } \\
\text { selection rationale }\end{array}$ & $\begin{array}{l}\text { The items had not identified teachers' reasoning in choosing particular online } \\
\text { media. They only reveal the information on the presence of schools' guidance } \\
\text { and counseling websites. }\end{array}$ \\
\hline \multirow[t]{2}{*}{5} & $\begin{array}{l}\text { Frequency of online } \\
\text { media usage in classical } \\
\text { guidance service }\end{array}$ & $\begin{array}{l}\text { 1. The items did not correspond with the item purpose to reveal the frequency } \\
\text { of online media usage. The provided items only reveal the information on the } \\
\text { frequently used guidance and counseling website menus. }\end{array}$ \\
\hline & & $\begin{array}{l}\text { 2. Inconsistencies on the concept of Internet, website, application, and media } \\
\text { had been observed. }\end{array}$ \\
\hline \multirow[t]{2}{*}{6} & $\begin{array}{l}\text { Frequency of online } \\
\text { media usage in } \\
\text { individual and group } \\
\text { counseling services }\end{array}$ & $\begin{array}{l}\text { 1. A discrepancy between the item formulation and the item purpose was } \\
\text { found. The item aimed to identify the frequency of online media usage, while } \\
\text { it revealed information on the reason for online media selection. }\end{array}$ \\
\hline & & 2. There was an error or typo. The word frequently was written as always. \\
\hline 7 & $\begin{array}{l}\text { Experts assisted online } \\
\text { guidance and counseling } \\
\text { media development. }\end{array}$ & The items were great. \\
\hline 8 & $\begin{array}{l}\text { Self-made guidance and } \\
\text { counseling media. }\end{array}$ & The technology and informatics concepts were overlapped. \\
\hline
\end{tabular}


Table 2. Results of Questionnaire Readability Test

\begin{tabular}{|c|c|c|c|}
\hline No & Aspect & Suggestions and Comments & $\begin{array}{l}\text { Number of } \\
\text { Respondents }\end{array}$ \\
\hline 1 & $\begin{array}{l}\text { The answer } \\
\text { formulation and } \\
\text { distractors }\end{array}$ & $\begin{array}{l}\text { The provided item formulations and distractors could be read and } \\
\text { comprehended easily. }\end{array}$ & 14 \\
\hline 2 & $\begin{array}{l}\text { The technique of } \\
\text { answer display }\end{array}$ & $\begin{array}{l}\text { It would be better if the participants were allowed to give the } \\
\text { open-ended answer by the 'other' option. }\end{array}$ & 3 \\
\hline 3 & $\begin{array}{l}\text { The technique of } \\
\text { answer display }\end{array}$ & $\begin{array}{l}\text { One of the required questions provides no correct answer, while } \\
\text { the participants were obligated to fill it, in order to submit their } \\
\text { responses. The connected question should be separated. }\end{array}$ & 2 \\
\hline 4 & $\begin{array}{l}\text { Online media } \\
\text { application }\end{array}$ & $\begin{array}{l}\text { Other than Google Meet and Zoom, some schools used Moodle, } \\
\text { Google Classroom, Edmodo, and Instagram. }\end{array}$ & 4 \\
\hline 5 & $\begin{array}{l}\text { The answer } \\
\text { example }\end{array}$ & $\begin{array}{l}\text { The answer alternatives for some items are confusing, so the } \\
\text { answer examples should be provided. }\end{array}$ & 1 \\
\hline 6 & $\begin{array}{l}\text { Counselors' } \\
\text { behavior and } \\
\text { response }\end{array}$ & $\begin{array}{l}\text { There should be items on school counselors' behavior and } \\
\text { response to online learning. }\end{array}$ & 1 \\
\hline 7 & Specific answer & $\begin{array}{l}\text { The answer should be explicitly made, primarily for the } \\
\text { definition of video call and voice notes. The online media that } \\
\text { provide video call features are WhatsApp, Google Meet, Zoom, } \\
\text { and Microsoft Teams, while the one with voice note feature is } \\
\text { WhatsApp. }\end{array}$ & 1 \\
\hline
\end{tabular}

\section{RESULTS}

The 106 participants involved in this study consist of $68.9 \%$ female and $31.1 \%$ male. The detailed information about the participants is presented in Table 3. Interestingly, most of the participants in this study are female school counselors with bachelor's degrees in guidance and counseling programs working in city private schools. Besides, the certified and uncertified teachers, the status of permanent and non-permanent teachers in the education institutions, and the level of junior and senior high school students were spread equally.

Table 3. Description of the Participants

\begin{tabular}{|c|c|c|}
\hline No & Criteria & Description \\
\hline 1 & Teaching certificate & $\begin{array}{l}52.8 \% \text { of participants have had a teaching certificate, while } 47.2 \% \text { do not have } \\
\text { it. }\end{array}$ \\
\hline 2 & Employment status & $\begin{array}{l}41.5 \%, 30.2 \% \text {, and } 18.9 \% \text { of the participants are permanent teachers in the } \\
\text { education institution, non-permanent institutional teachers, and civil servants, } \\
\text { respectively. Meanwhile, the remaining participants are auxiliary, honorary, } \\
\text { province-contract, and non-permanent state school teachers. }\end{array}$ \\
\hline 3 & Educational level & $\begin{array}{l}95.3 \% \text { of the participants have the guidance and counseling bachelor's } \\
\text { degree. }\end{array}$ \\
\hline 4 & $\begin{array}{l}\text { The level of schools they } \\
\text { work for }\end{array}$ & $\begin{array}{l}45.3 \%, 49.1 \% \text {, and } 5.6 \% \text { of the participants work in junior, senior, and } \\
\text { vocational high schools, respectively. }\end{array}$ \\
\hline 5 & $\begin{array}{l}\text { The level of schools they } \\
\text { work for }\end{array}$ & $\begin{array}{l}67.9 \%, 24.5 \% \text {, and } 7.5 \% \text { of their schools are private, state, and private } \\
\text { national schools, respectively. }\end{array}$ \\
\hline 6 & Location of the schools & $\begin{array}{l}64.2 \%, 18.9 \% \text {, and } 17 \% \text { of the schools are located in the city, districts, and } \\
\text { regency, respectively. }\end{array}$ \\
\hline 7 & $\begin{array}{l}\text { The economic status of } \\
\text { the students }\end{array}$ & $\begin{array}{l}41.5 \%, 30.2 \% \text {, and } 25.5 \% \text { of their students have middle to high, middle, and } \\
\text { middle to low economic status. Meanwhile, the remaining of their students } \\
\text { have high and low financial status. }\end{array}$ \\
\hline
\end{tabular}




\section{Online Media Frequently Used in Classical Guidance Services}

Commonly, schools provide scheduled classical guidance services every week (72\%). Most of the school counselors use Google Form (69\%), Video Maker (60\%), and non-narrated PowerPoint (57\%) to create the materials for their group guidance services, as illustrated in Figure 1. In addition, $50 \%$ of the schools' counselors put Google Classroom as their most frequently used online media. The frequency of Google Classroom usage is higher than Zoom and Video Conference, as presented in Figure 2. Zoom and Video Conference enables the counselor to hold a synchronous meeting, while they can have an asynchronous discussion using Google Classroom, audio slide PowerPoint, Google Form, and WhatsApp Speech Rapid.

\section{Online Media Frequently Used in the Individual and Group Counseling Services}

Essentially, there are three types of online or cyber counseling, namely textual, audio, and audiovisual. The most recurrent online media used for online counseling is WhatsApp chat $(90 \%)$, followed by Live Instagram, while the voice note has almost never been used, as presented in Figure 3. It signifies that online textual counseling is the most used counseling type.

\section{The Reasoning for the Online Media Selection in the Classical or Group Counseling}

The students' Internet accessibility (77\%) becomes the primary consideration for the online media selection, followed by students' technological competencies (68\%) and their financial capability $(67 \%)$, as presented in Figure 4. Therefore, the considerations of online media selection mostly lie in students' situations.

\section{The Deliberation of Online Media Selection for Individual or Group Counselling}

Similar to the media selection for classical guidance, the consideration of online media selection in individual or group counseling also mostly relies on students' situations. $74 \%$ of participants consider their students' internet accessibility, $73 \%$ consider confidentiality assurance, while $63 \%$ and $64 \%$ consider the students' financial and technological ability, as presented in Figure 5.

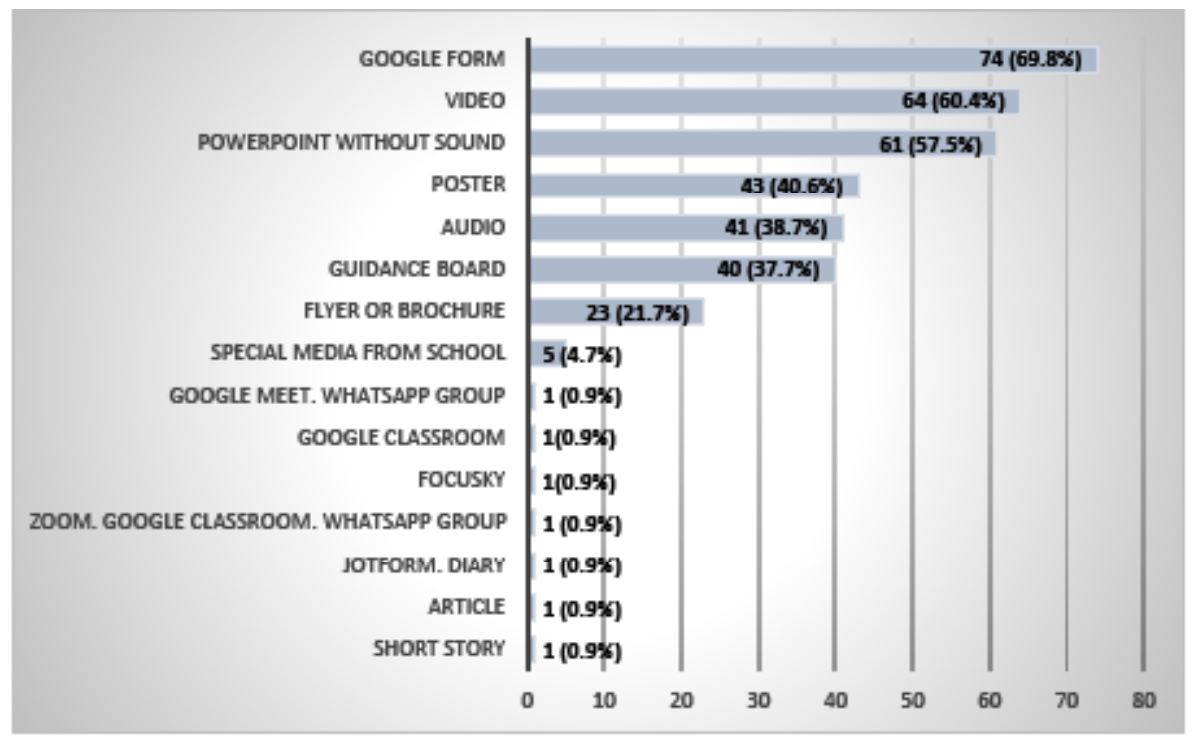

Figure 1. Media Used in the Formulation of Guidance and Counseling Materials 


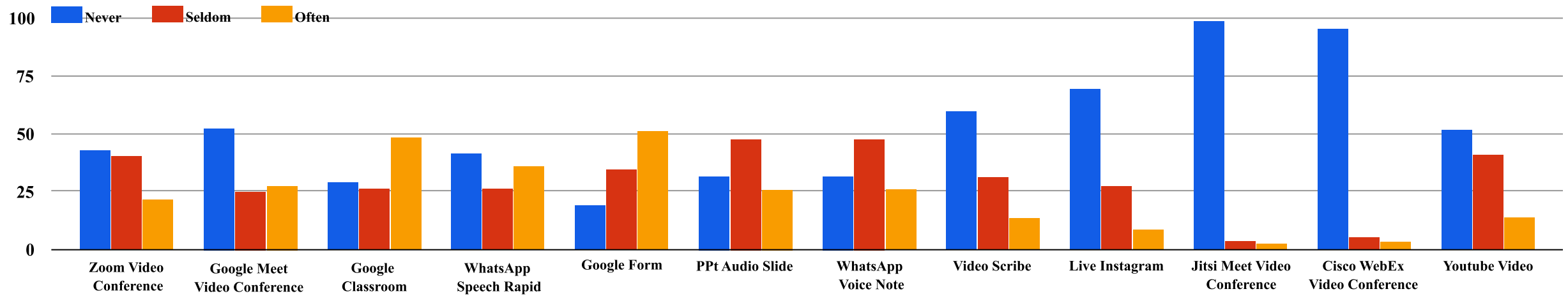

Figure 2. The Frequency of Online Application and Media Usage

100

25

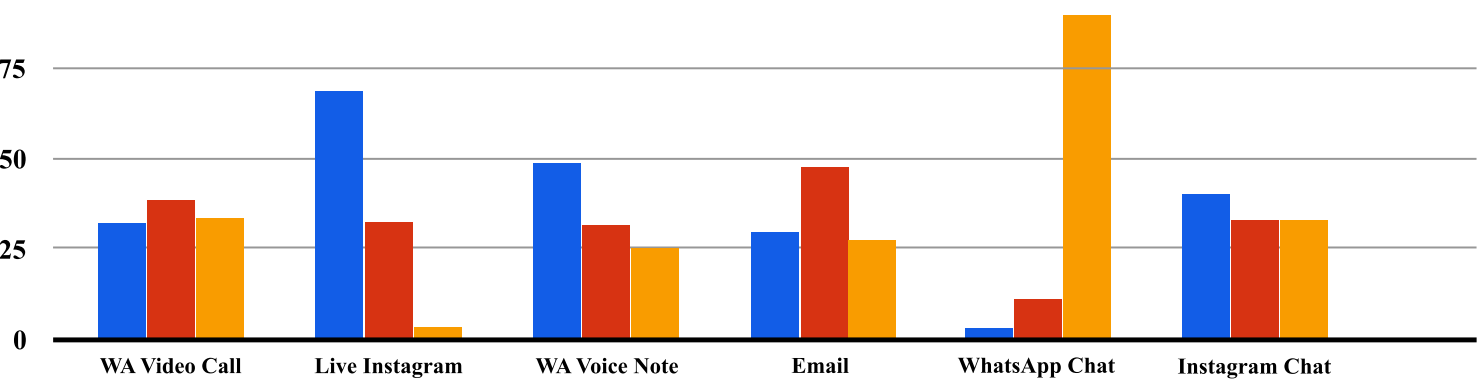

Figure 3. The Frequency of Online Application Usage in Counseling Process 


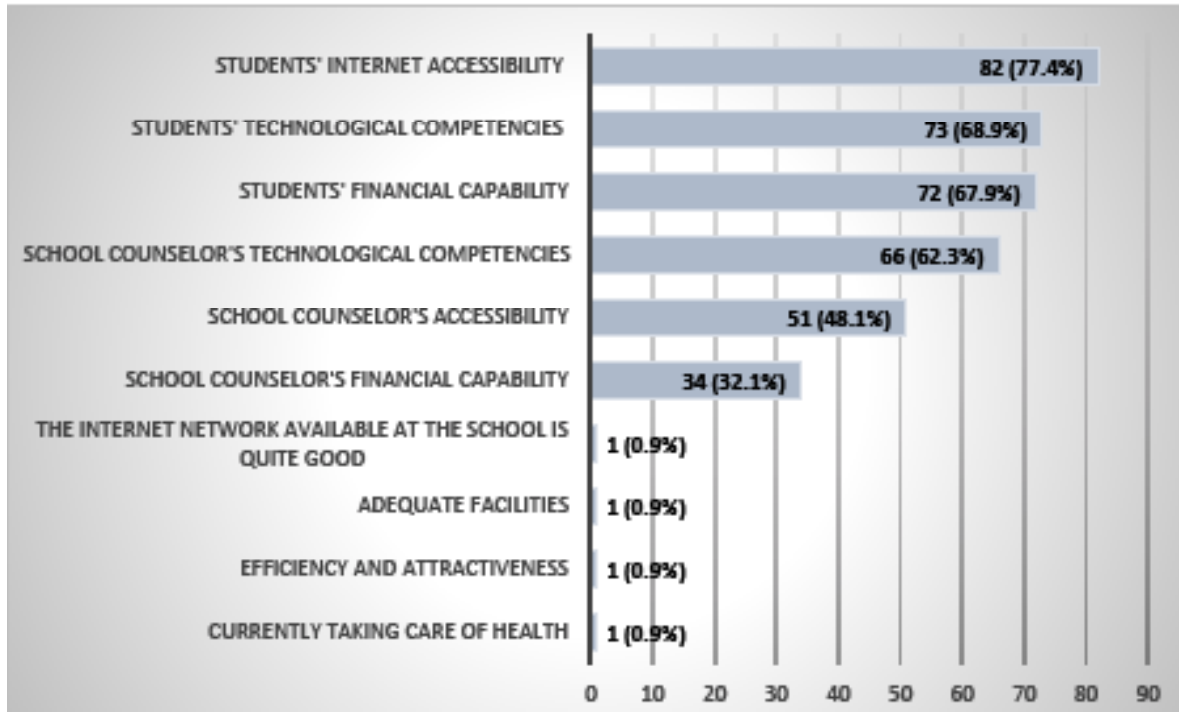

Figure 4. Consideration of Online Media Selection in the Classical or Group Counseling

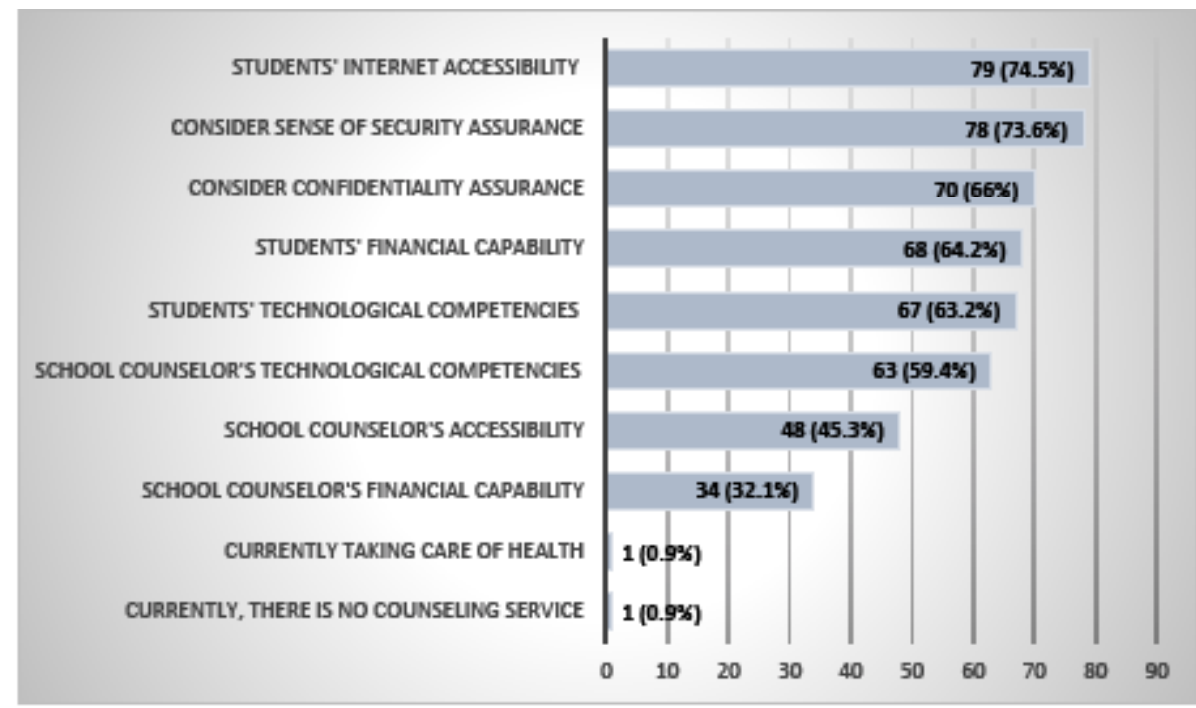

Figure 5. Deliberation of Online Media Selection for Individual and Group Counseling

\section{DISCUSSION}

Due to the current Covid-19 pandemic, guidance and counseling services are carried out online, so Internet accessibility and stability become essential. Consequently, asynchronous counseling held through Google Classroom becomes a relatively reasonable choice for school counselors. Furthermore, Google Classroom provides uncomplicated access for the teachers and students to hold the learning process at any time and place, with the Internet connection (Nurhayati, Az-Zahra, \& Herlambang, 2019; Putri \& Dewi, 2019; Widyantara, 2020).

The flexibility and accessibility of Google Classroom have increased the efficiency of the distanced learning (Wijaya, 2016). Additionally, Google Classrooms also simplify the materials delivery, students' work submission, the scoring process, teacher-students communication, time management, and mobile application access (Bakhtiar, Wulandari, \& Marlina, 2019). Thus, Google Classroom carries excellent features for classical guidance. Recently, Google Classroom also can serve as the information carrier (Pustika, Astuti, \& Suratman, 2019). However, other than those superior qualities, Google Classroom also possesses a number of weaknesses. First, the interaction dynamics between the school counselors and students in this media tend to only focus on materials delivery. Besides, it has minimum features that may bring confusion for its users. 
In addition to Google Classroom, Google Forms has facilitated the online guidance process since it offers a number of beneficial facilities (Aji, Nurpitasari, Hanum, Akbar, \& Putra, 2020). In detail, Google Form can be used to: (1) disseminate questionnaires to the students, (2) filing of the assessment results since the responses are automatically stored in Google Drive, and (3) spend the time efficiently (Batubara, 2016; Mulatsih, 2020).

Online counseling can be complicated (Ifdil \& Ardi, 2013; Kirana, 2019; Prasetya, 2017). The minimum internet access accessibility and financial capability is one of the obstacles in the online counseling services. In this study, online counseling is mainly carried out synchronously through chat and textually. The synchronous mode is selected due to the students' Internet accessibility and stability, financial state, and technological competencies. Besides, a proper Internet connection is highly required in online counseling. Even online counseling through video calls can be felt like face-to-face counseling with a speedy Internet connection (Pasmawati, 2016).

This study identifies that the students mostly have sufficient financial ability to attend online learning. Consequently, the chatting method might have been selected due to students' frequent smartphone access rather than laptops. In contrast, a study carried out by Fauzi, Heiriyah, \& Matarif (2020) show that the online guidance and counseling services was obstructed by the students' inability to purchase smartphone and Internet quota, as well as slow phone response. It indicates the diverse situation in the online guidance services. From the perspective of the school counselors, synchronous counseling is selected due to their skills and views on their students' situations.

Petrus \& Sudibyo (2017) state that people have the tendency to efficiently communicate their idea and feel when they are unobserved and give no verbal sign during the counseling process. Linear to this idea, counseling online is popular for the people who are afraid to attend or being cautious in faceto-face counseling (Barnett, 2005; Lange, Van De Ven, \& Schrieken, 2003). Besides, the geographical (Sussman, 2004) and physical limitation sometimes also become the reason why people choose online counseling (Maples \& Han, 2008).

In Malaysia, online counseling has grown rapidly and gains positive responses from counselors. However, most of the counselors still prefer face-to-face counseling (Zamani, Nasir, \& Yusooff, 2010). A survey involving 409 Malaysian college students reveals that $35 \%$ of the respondents prefer online counseling and do not wish to participate in face-to-face counseling. It indicates that most of the students like online counseling better than face-to-face counseling (Wong, Bonn, Tam, \& Wong, 2018).

The WhatsApp application is adopted in online counseling due to its simplicity and students' dominating Internet connection issues. People have been highly familiarized with the WhatsApp application. Besides, this application also offers personal and group chat features that enable individual and group counseling implementation. A study also suggests that the WhatsApp application is selected in the counseling process due to its simplicity and flexibility (Puspita, Elita, \& Sinthia, 2020; Sukoco KW \& Budiman S, 2019). Also, this application can be improved easily (Budianto, Hidayah, \& Aziz, 2019). Other than WhatsApp, email and video calls have been observed to be used in the cyber counseling process. However, the Internet connection issue has forced school counselors to avoid the use of video calls. Besides, the massive adoption of WhatsApp for the cyber counseling process in Indonesia suggests that synchronous communication through chat has been popular in this country. Also, another study shows that individual counseling through chatting is more effective than counseling through video (Barak, Hen, Boniel-Nissim, \& Shapira, 2008; Dowling \& Rickwood, 2013).

\section{CONCLUSION}

The school counselors have massively used Google Classroom in the classical or group guidance due to its accessibility and excellent features. Meanwhile, Google Form is observed to be frequently used to gather and analyze the students' data. For individual or group counseling, WhatsApp becomes the most popular application since it requires no strong Internet connection and is accessible. The results of this study can be used as the fundamental to improve school counselors' technological literacy and competencies required in online synchronous and asynchronous guidance and counseling services. Their technological competencies can be enhanced through intensive training. 


\section{REFERENCES}

Aji, B. S., Nurpitasari, E., Hanum, N. C., Akbar, A. A., \& Putra, C. (2020). Pengembangan asesmen berbasis teknologi untuk keberlangsungan BK ditengah pandemi Covid-19.

Bakhtiar, M. I., Wulandari, R., \& Marlina, E. (2019). Layanan bimbingan klasikal menggunakan media konseling berbasis teknologi aplikasi Google Classroom. Konvensi Nasional XXI Asosiasi Bimbingan dan Konseling Indonesia, 78-81.

Bambling, M., King, R., Reid, W., \& Wegner, K. (2008). Online counselling: The experience of counsellors providing synchronous single-session counselling to young people. Counselling and Psychotherapy Research, $8(2), 110-116$.

Bangun, N. B., \& Saragih, A. H. (2015). Pengembangan media web bimbingan konseling. Jurnal Teknologi Informasi \& Komunikasi dalam Pendidikan, 2(1), 99-110.

Barak, A., Hen, L., Boniel-Nissim, M., \& Shapira, N. (2008). A comprehensive review and a meta-analysis of the effectiveness of internet-based psychotherapeutic interventions. Journal of Technology in Human Services, 26(2-4), 109-160.

Barak, A., Klein, B., \& Proudfoot, J. G. (2009). Defining internet-supported therapeutic interventions. Annals of Behavioral Medicine, 38(1), 4-17.

Barnett, J. E. (2005). Online counseling: New entity, new challenges. The Counseling Psychologist, 33(6), 872880.

Batubara, H. H. (2016). Penggunaan Google Form sebagai alat penilaian kinerja dosen di Prodi PGMI Uniska Muhammad Arsyad Al Banjari. Al-Bidayah: Jurnal Pendidikan Dasar Islam, 8(1).

Boshra, A. A., Al-Dabbagh, Z. S., Al Eid, N. A., Al Eid, M. A., Al-Musaibeh, S. S., Al-Miqtiq, M. N., ... Al-Zeyad, G. M. (2020). The effects of corona virus (COVID-19) outbreak on the individuals' mental health and on the decision makers: A comparative epidemiological study. International Journal of Medical Research \& Health Sciences, 9(3), 26-47.

Budianto, A. E., Hidayah, N., \& Aziz, A. (2019). Aplikasi cyber counseling dengan mengoptimalkan Whatsapp berbasis komputasi mobile. Kurawal - Jurnal Teknologi, Informasi dan Industri, 2(2), 182-193. https://doi. org/10.33479/kurawal.2019.2.2.182-193

Chester, A., \& Glass, C. A. (2006). Online counselling: A descriptive analysis of therapy services on the Internet. British Journal of Guidance \& Counselling, 34(2), 145-160.

Chu, D. K., Akl, E. A., Duda, S., Solo, K., Yaacoub, S., Schünemann, H. J., ... Schünemann, H. J. (2020). Physical distancing, face masks, and eye protection to prevent person-to-person transmission of SARS-CoV-2 and COVID-19: A systematic review and meta-analysis. The Lancet, 395(10242), 1973-1987. https://doi. org/10.1016/S0140-6736(20)31142-9

Dowling, M., \& Rickwood, D. (2013). Online counseling and therapy for mental health problems: A systematic review of individual synchronous interventions using chat. Journal of Technology in Human Services, 31(1), 1-21. https://doi.org/10.1080/15228835.2012.728508

Fauzi, Z., Heiriyah, A., \& Matarif, J. (2020). Upaya pelayanan guru bimbingan dan konseling selama pandemi Covid-19 pada siswa di SMP Negeri 23 Banjarmasin. Jurnal Mahasiswa BK An-Nur, 1(1), 1-12.

Ifdil, I., \& Ardi, Z. (2013). Konseling online sebagai salah satu bentuk pelayanan e-konseling. Jurnal Konseling dan Pendidikan, 1(1), 15-21. https://doi.org/10.29210/1400

Karaman, M. A., Eşici, H., Tomar, İ. H., \& Aliyev, R. (2021). COVID-19: Are school counseling services ready? Students' psychological symptoms, school counselors' views, and solutions. Frontiers in Psychology, 12, 647740. https://doi.org/10.3389/fpsyg.2021.647740

Kirana, D. L. (2019). Cyber counseling sebagai salah satu model perkembangan konseling bagi generasi milenial. Al-Tazkiah, 8(1), 57-61.

Koh, W. C., Naing, L., \& Wong, J. (2020). Estimating the impact of physical distancing measures in containing COVID-19: An empirical analysis. International Journal of Infectious Diseases, 100, 42-49. https://doi. org/10.1016/j.ijid.2020.08.026

Lange, A., Van De Ven, J.-P., \& Schrieken, B. (2003). Interapy: treatment of post-traumatic stress via the internet. Cognitive Behaviour Therapy, 32(3), 110-124.

Lau, P. L., Jaladin, R. A. M., \& Abdullah, H. S. (2013). Understanding the two sides of online counseling and their ethical and legal ramifications. Procedia - Social and Behavioral Sciences, 103, 1243-1251. https://doi. org/10.1016/j.sbspro.2013.10.453 
Liebrenz, M., Bhugra, D., Buadze, A., \& Schleifer, R. (2020). Caring for persons in detention suffering with mental illness during the Covid-19 outbreak. Forensic Science International. Mind and Law, 1, 100013.

Mansyur, A. I., Badrujaman, A., Imawati, R., \& Fadhillah, D. N. (2020). Konseling online sebagai upaya menangani masalah perundungan di kalangan anak muda. Jurnal Pendidikan Ilmu Sosial, 29(2), 140-154. https://doi. org/10.23917/jpis.v29i2.8501

Maples, M. F., \& Han, S. (2008). Cybercounseling in the United States and South Korea: Implications for counseling college students of the millennial generation and the networked generation. Journal of Counseling \& Development, 86(2), 178-183. https://doi.org/10.1002/j.1556-6678.2008.tb00495.x

Meleo-Erwin, Z., Kollia, B., Fera, J., Jahren, A., \& Basch, C. (2021). Online support information for students with disabilities in colleges and universities during the COVID-19 pandemic. Disability and Health Journal, 14(1), 101013. https://doi.org/10.1016/j.dhjo.2020.101013

Mulatsih, B. (2020). Penerapan aplikasi Google Classroom, Google Form, dan Quizizz dalam pembelajaran kimia di masa pandemi Covid-19. Ideguru: Jurnal Karya Ilmiah Guru, 5(1), 16-26.

Musdalifah, A. (2020). Media layanan bimbingan dan konseling di tengah pandemi Covid-19. Prosiding Seminar \& Lokakarya Nasional Bimbingan dan Konseling, 59-64.

Nugroho, G. B. (2020). Peran guru bimbingan dan konseling dalam pendampingan belajar siswa selama pembelajaran online. Psiko Edukasi, 18(1), 73-83.

Nurhayati, D., Az-Zahra, H. M., \& Herlambang, A. D. (2019). Evaluasi user experience pada Edmodo dan Google Classroom menggunakan technique for user experience evaluation in e-learning (TUXEL)(Studi Pada SMKN 5 Malang). Jurnal Pengembangan Teknologi Informasi dan Ilmu Komputer, 3(4), 3771-3780.

Pasmawati, H. (2016). Cyber counseling metode pengembangan layanan kounseling di era global. Jurnal Ilmiah Syi'ar, 16(1), 5-7.

Perdana, M. A. P. A., \& Shofaria, N. (2020). Inovasi layanan bimbingan dan konseling pada pembelajaran dalam jaringan masa pandemi Covid-19. Jurnal Bikotetik (Bimbingan dan Konseling: Teori dan Praktik), 4(2), 55-61. https://doi.org/10.26740/bikotetik.v4n2.p55-61

Petrus, J., \& Sudibyo, H. (2017). Kajian konseptual layanan cyberconseling. Konselor, 6(1), 6-12. https://doi. org/10.24036/02017616724-0-00

Prabawa, A. F., Ramli, M., \& Fauzan, L. (2018). Pengembangan website cybercounseling realita untuk meningkatkan keterbukaan diri siswa sekolah menengah kejuruan. Jurnal Kajian Bimbingan dan Konseling, 3(2), 59-68. https://doi.org/10.17977/um001v3i22018p059

Prahesti, Y., \& Wiyono, B. D. (2017). Pengembangan website konseling online untuk siswa di SMA negeri 1 Gresik. Jurnal BK Unesa, 7(3), 144-154.

Prasetya, A. F. (2017). Model cyber counseling: Telaah konseling individu online chat-asychronous berbasis aplikasi android. Prosiding Seminar Bimbingan dan Konseling, 1(1), 31-38.

Puspita, D., Elita, Y., \& Sinthia, R. (2020). Pengaruh layanan konseling kelompok berbasis cyber-counseling via whatsapp terhadap keterbukaan diri mahasiswa bimbingan dan konseling semester 4a Universitas Bengkulu. Consilia : Jurnal Ilmiah Bimbingan dan Konseling, 2(3), 271-281. https://oi.org/10.33369/ consilia.2.3.271-281

Pustika, D., Astuti, I., \& Suratman, D. (2019). Pengembangan media layanan informasi karir berbasis Google Classroom di sekolah menengah kejuruan. Jurnal Pendidikan dan Pembelajaran Khatulistiwa, 8(12), 1-9.

Putri, G. K., \& Dewi, Y. A. S. (2019). Pengaruh model pembelajaran jarak jauh berbasis Google Classroom. $A L-$ FIKRAH: Jurnal Studi Ilmu Pendidikan dan Keislaman, 2(1), 60-79.

Qureshi, A. I., Suri, M. F. K., Chu, H., Suri, H. K., \& Suri, A. K. (2021). Early mandated social distancing is a strong predictor of reduction in peak daily new COVID-19 cases. Public Health, 190, 160-167. https://doi. org/10.1016/j.puhe.2020.10.015

Sammer, M. B. K., Sher, A. C., Huisman, T. A. G. M., \& Seghers, V. J. (2020). Response to the COVID-19 pandemic: Practical guide to rapidly deploying home workstations to guarantee radiology services during quarantine, social distancing, and stay home orders. American Journal of Roentgenology, 215(6), 1417-1420. https://doi.org/10.2214/AJR.20.23297

Savić, D. (2020). COVID-19 and work from home: Digital transformation of the workforce. Grey Journal (TGJ), $16(2), 101-104$.

Setyawan, B. (2019). Pengembangan media Google Site dalam bimbingan klasikal di SMAN 1 Sampung. Jurnal Nusantara of Research, 6(2), 78-87. 
Sholihah, I. N., \& Handayani, T. (2020). Pemanfaatan teknologi dalam layanan bimbingan dan konseling di tengah pandemi Covid 19. Prosiding Seminar \& Lokakarya Nasional Bimbingan dan Konseling 2020, (1), 477-482.

Situmorang, D. D. B. (2020). Online/cyber counseling services in the COVID-19 outbreak: Are they really new? The Journal of Pastoral Care \& Counseling : JPCC, 74(3), 166-174. https://doi.org/10.1177/1542305020948170

Sukoco KW, \& Budiman S, M. A. (2019). Konseling individu melalui cyber counseling terhadap pembentukan konsep diri peserta didik. Bikotetik (Bimbingan dan Konseling: Teori dan Praktik), 3(1), 6-10. https://doi. org/10.26740/bikotetik.v3n1.p6-10

Supriyanto, A., Hartini, S., Irdasari, W. N., Miftahul, A., Oktapiana, S., \& Mumpuni, S. D. (2020). Teacher professional quality: Counselling services with technology in Pandemic Covid-19. Counsellia: Jurnal Bimbingan dan Konseling, 10(2), 176-189. https://doi.org/10.25273/counsellia.v10i2.7768

Sussman, R. J. (2004). Cyberbytes: Highlighting compelling uses of technology in counseling. In G. R. Waltz \& C. Kirkman (Eds.), Counseling over the Internet: Benefits and challenges in the use of new technologies (pp. 17-20). ERIC.

Sutijono, S., \& Farid, D. A. M. (2018). Cyber counseling di era generasi milenial. Sosiohumanika, 11(1), $19-23$.

Widyantara, V. (2020). Konsep, penggunaan, perbandingan, kelebihan dan kekurangan serta implikasi Google Classroom sebagai media pembelajaran jarak jauh. Jakarta State University, (May), 1-5.

Wijaya, A. (2016). Analysis of factors affecting the use of Google Classroom to support lectures. The 5th International Conference on Information Technology and Engineering Application (ICIBA2016), 61-68. Bina Darma University.

Wong, K. P., Bonn, G., Tam, C. L., \& Wong, C. P. (2018). Preferences for online and/or face-to-face counseling among university students in Malaysia. Frontiers in Psychology, 9(Jan), 1-5. https://doi.org/10.3389/ fpsyg.2018.00064

Zamani, Z. A., Nasir, R., \& Yusooff, F. (2010). Perceptions towards online counseling among counselors in Malaysia. Procedia - Social and Behavioral Sciences, 5, 585-589. https://doi.org/10.1016/j.sbspro.2010.07.146 